\title{
Electrical Resistivity Tomography for Sustainable Groundwater Development in a Complex Geological Area
}

\section{Električna Upornostna Tomografija v Razvoju Sonaravne Oskrbe z Vodo v Kompleksnem Geološkem Območju}

\author{
Adedibu Sunny Akingboye, Isaac Babatunde Osazuwa, Muraina Zaid Mohammed \\ Department of Earth Sciences, Adekunle Ajasin University, P.M.B. 001, Akungba-Akoko, Ondo State, Nigeria \\ adedibu.akingboye@aaua.edu.ng, iosazuwa@yahoo.com,muraina.mohammed@aaua.edu.ng
}

\begin{abstract}
Electrical resistivity tomography (ERT) was used for delineating significant subsurface hydrogeological features for sustainable groundwater development in Etioro-Akoko area, Southwestern Nigeria. This study was necessitated by challenges posed on groundwater supplies from wells and boreholes in Etioro-Akoko and the neighbouring fast growing towns and villages. Field data were acquired over the area with ABEM Lund Resistivity Imaging System and were subsequently processed and inverted through RES2DINVx64 software. Results showed four distinct subsurface layers: topsoil, weathered layer, fractured bedrock and fresh bedrock (basal unit). Localised bedrock depressions occasioned by fracturing and deep weathering of less stable bedrock minerals were delineated with resistivity and thickness values ranging from 50 to $650 \Omega \mathrm{m}$ and 12 to $>25 \mathrm{~m}$, respectively. The localised depressions mirrored uneven bedrock topography and served as the preferential groundwater storage and hydrogeological zones in the area. The two hydrogeological zones significant for groundwater development included overburden-dependent aquifers and fractured dependent bedrock aquifers. It was, therefore, concluded that groundwater storage potential was depended on hydrogeological zones particularly at major localised bedrock depressions where fractures and groundwater recharges/discharges were evident. Wells and boreholes were proposed at bedrock depressions with thickness value not less than 12 and > $25 \mathrm{~m}$, respectively, for enhanced groundwater sustainability and quality assurance in the area.
\end{abstract}

Key words: electrical resistivity tomography (ERT), subsurface conduits, hydrogeological zones, groundwater, Etioro-Akoko.

\section{Povzetek}

Električno upornostno tomografijo (Electrical Resistivity Tomography, ERT) so uporabili za omejitev hidrogeoloških značilnosti, pomembnih za oceno potenciala talne vode na območju Etioro-Akoko v jugozahodni Nigeriji. Potrebo po študiji so sprožile težave oskrbe $\mathrm{s}$ podtalnico iz vodnjakov in vrtin $\mathrm{v}$ Etioro-Akoku in sosednjih naglo razvijajočih se mestih in vaseh. Terenske podatke s področja so pridobili z ABEM Lundovim upornostnim prikazovalnim sistemom in jih zatem obdelali z računalniško opremo RES2DINVx64. Rezultati so nakazali štiri različne podpovršinske nivoje: vrhnja tla, preperinska plast, kamnine razpokane podlage in nepreperele kamnine podlage. Lokalizirane depresije $\mathrm{v}$ podlagi, nastale $\mathrm{z}$ drobljenjem in globokim preperevanjem manj obstojnih mineralov v kamninah podlage so omejili z dobljenimi vrednostmi upornosti in debeline na 50-650 $\Omega$ m oziroma 12 - > $25 \mathrm{~m}$. Ugotovljene depresije, ki nakazujejo neravno površino podlage, predstavljajo ugodne hidrogeološke cone za zbiranje vode na raziskovanem območju. Dve hidrogeološki coni, obetavni za razvoj vodnih virov, obsegata vodonosnike, vezane na prekritje in vodonosnike $\mathrm{v}$ razpokani kamnini podlage. Raziskavo so zato sklenili z ugotovitvijo, da je potencial vodnih zalog odvisen od hidrogeoloških con zlasti v glavnih ugotovljenih depresijah podlage, kjer so očitni razpokanost in sledovi gibanja podtalnice. Lokacije vodnjakov in vrtin so predlagali nad depresijami podlage z vrednostmi debeline vsaj $12 \mathrm{~m}$, oziroma nad $25 \mathrm{~m}$ za zagotovitev boljše trajnosti in kakovosti oskrbe $\mathrm{z}$ vodo na tem območju.

Ključne besede: električna upornostna tomografija (ERT), podzemni kanali, hidrogeološke cone, podtalnica; Etioro-Akoko. 


\section{Introduction}

Globally, people express a desire for abundant and potable groundwater for consumption and other purposes. Thus, exploration for the abundance of this hidden resource in the subsurface necessitates advancement in electrical resistivity imaging via the development of fast automated multi-electrode array systems and new inversion algorithms [1-5]. These systems clearly reveal the characteristics and conditions of the subsurface geology for sustainable groundwater development, particularly in the areas of complex geology.

Exploitation of groundwater in basement terrain depends on weathering thickness and bedrock structures such as grabens and fractures. Generally, overburden thicknesses are somewhat very thin across some sections of the Southwestern Basement Complex of Nigeria [6]. This development leaves aquifer systems in substantial parts of the terrain with few localised subsurface structures and bedrock depressions serving as conduits for groundwater recharge and storage, respectively. However, the unconfined and near-surface nature of most aquifer systems within the basement terrain may be challenged by contamination arising from surficial impurities and run-offs. Therefore, groundwater deficit due to thin overburden and vulnerability is evident in the study area.

Geophysical investigations using both conventional electrical resistivity and other integrated geophysical probes have been carried out in parts of Etioro-Akoko with its adjoining towns in the recent past. The efforts have been to determine aquifer regimes and potentials, as well as subsurface geology [6-8]. Moreover, borehole projects such as Kamomi water project and mechanised handpump borehole have been conducted in the study area. However, these investigations have not fully solved the challenges posed on groundwater supplies in the area. Lack of good knowledge of the subsurface strata, bedrock topography, bedrock structures and degree of the susceptibility of the aquifers in the area are possible challenges. Therefore, groundwater resources in EtioroAkoko must be developed and exploited in a sustainable manner.
Studies have shown that there exists a direct relationship between electrical resistivity and geological factors such as soil water content, lithology, size and pores, as well as fluid saturating the pores $[6,9,10]$. Earth materials are generally resistive, and the presence of groundwater decreases the resistivity of total saturated volume of rock/deposit. Consequently, ERT remains a versatile technique for evaluating these geological factors for groundwater development and sustainability. ERT is a non-invasive surveying technique that images the subsurface from electrical resistivity measurements made at the earth's surface along a series of constant traverse separation with increasing electrode spacing at successive station positions $[1,5,11]$. This study, therefore, aimed at determining viable subsurface hydrogeological zones for groundwater development in Etioro-Akoko, a complex geological area where a layer of aquitard developed on the thin overburden, through the delineation of subsurface layers, structures/weak zones, and aquifer geometry and productivity.

\section{Location and Geological Setting}

Etioro-Akoko is located along Owo - Ikare-Akoko road in Akoko Southwest Local Government Area of Ondo State, Nigeria. It is located between latitudes $07^{\circ} 26^{\prime}$ and $07^{\circ} 27^{\prime} \mathrm{N}$ and longitudes $005^{\circ} 43^{\prime}$ and $005^{\circ} 44^{\prime} \mathrm{E}$ (Figure 1). The adjoining towns include the following: Ayegunle and Oba-Akoko to the South, Supare-Akoko to the West, Akungba-Akoko to the North and Iwaro and Oka-Akoko to the Northeast of the study area.

Etioro-Akoko is located in the tropical rainforest belt of Nigeria. The climate is dictated by the southwestern monsoon winds characterised by the tropical wet and dry climate. Rain starts in March with peaks during July to September while the dry season starts between October and November with annual mean variation between 1000 and $1500 \mathrm{~mm}$ [12]. The general pattern of drainage in the area is dendritic except in few cases where trellis patterns are observed. The area is characterised by three distinct landforms, which include hills, plains and valleys; these together constitute the topographic relief of the area, generally with aver- 


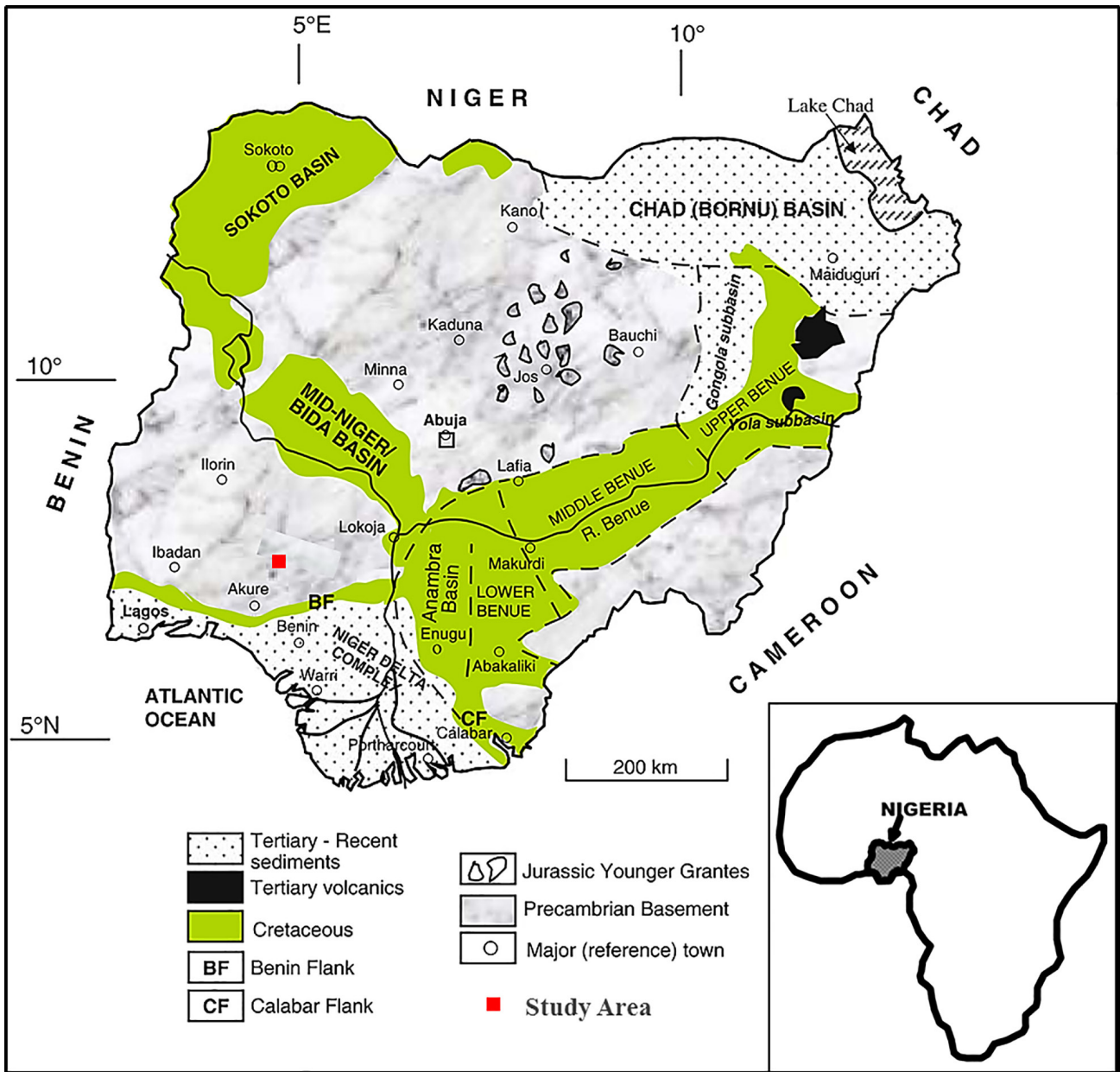

Figure 1: Geological map of Nigeria showing the study area (modified after [14]) [Inset: Map of Africa showing Nigeria].

age elevation between 320 and $350 \mathrm{~m}$ above the mean sea level.

The area is underlain by rocks of the Migmatite-Gneiss Complex of the Precambrian Southwestern basement rocks of Nigeria [13] (Figure 1). The rocks in the area include granite gneiss which is the widely spread rock and other minor intrusives such as aplite, pegmatite and vein quartz. The rocks show great variations in grain size and in mineral composition. The overburden in the area is generally thin. The basement outcrops in few places across the area. The basement rocks of the area have undergone at least two episodes of tectonic deformation, which have helped in the development of a series of simple and complex structures in the rocks.

\section{Materials and Methods}

The study involved a reconnaissance geological survey for field observation of the various rock types in the area. This was followed by geo-reference/establishment of geophysical traverses across the areas of interest to produce a geophysical acquisition map and selection of the array/protocol type for the resistivity field measurements.

\section{Field Measurements}

The ABEM Lund Resistivity Imaging System was used for the data collection. The field data acquisition employed the use of ABEM Tetrameter SAS 4000 Resistivity Meter, two sets of $100 \mathrm{~m}$ cable reels with pinouts of $5 \mathrm{~m}$ spacing, a 64-electrode unrestricted electrode selector (switching unit) - ES 10-64C, a set of 41 stainless steel electrodes and a car battery. Cables 


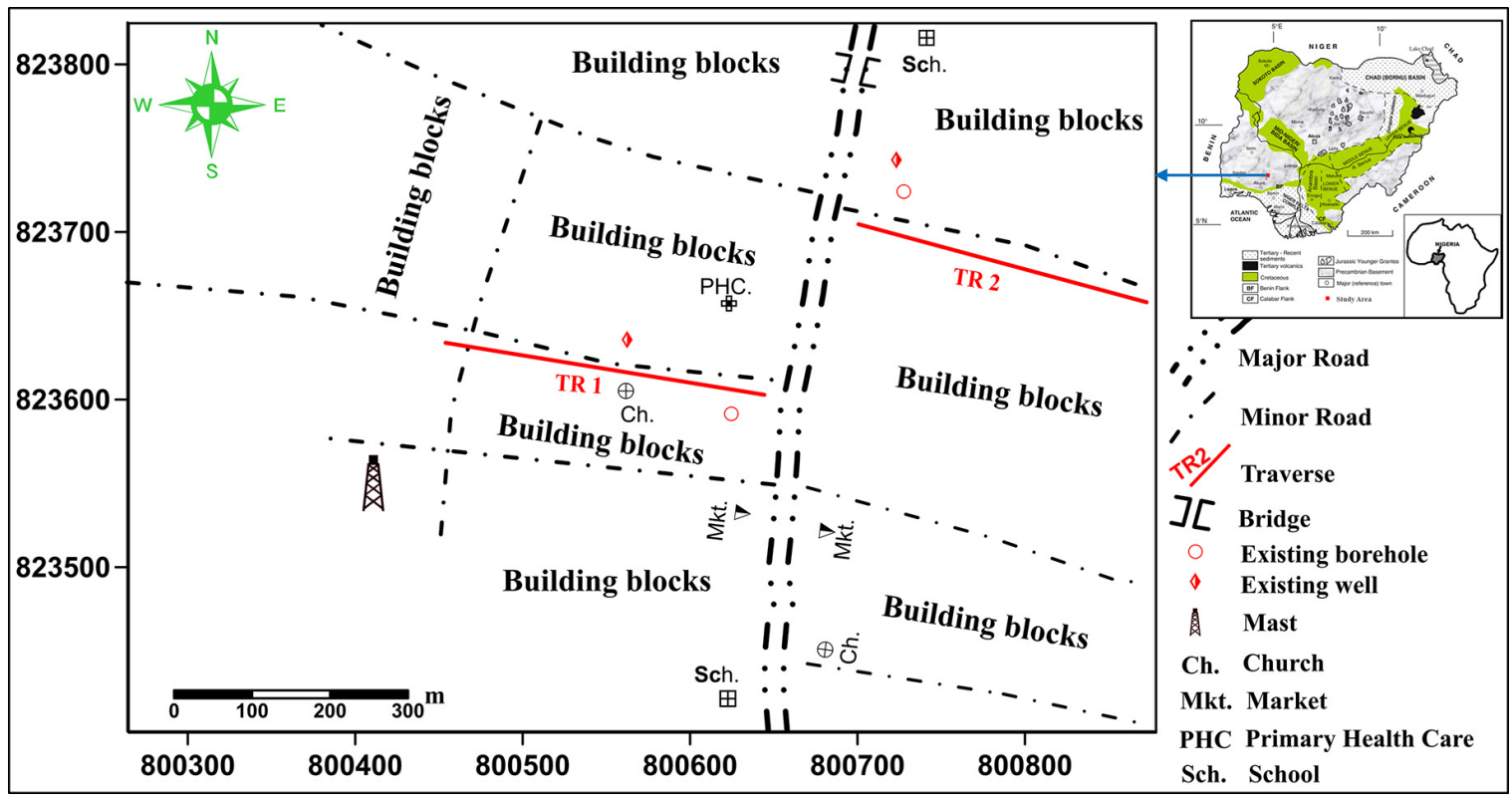

Figure 2: Data acquisition map of the study area.

were laid out and pinouts were connected to the grounded electrodes via cable jumpers. This was followed by the connection of the two terminal ends of the multicore cables to the electrode selector, and the electrode selector was then connected to the resistivity metre by a special cable. The resistivity metre was switched on after being connected to the car battery to select the array protocol (array configuration), and other measurement settings were adjusted for the measurements to be taken automatically.

In this study, the Wenner protocol was employed for the tomographic surveying due to its high signal-to-noise ratio and resolution. Measurements were acquired along two traverses (TRs 1 and 2) in the study area (Figure 2). TR 1 was laid approximately in E-W direction along Iyanu Jesu Street, where the Kamomi borehole was situated while TR 2 was laid about $50 \mathrm{~m}$ away along a street vertically opposite to TR 1 . The topography of TR 2 is rugged, showing a low-lying basement outcrop of about $15 \mathrm{~m}$ extent from station $100 \mathrm{~m}$ and plunges downward towards the eastern end of the traverse. Each of the traverses (TRs 1 and 2) has a spread length of $200 \mathrm{~m}$, with a spacing of $5 \mathrm{~m}$ between the respective electrodes.

\section{Field Data Processing and Inversion}

The field converted apparent resistivity data from .s $4 \mathrm{k}$ to .dat format through SAS 4000 Utility software were reduced, inverted and modelled sequentially by using RES2DINVx64 software. The data reduction phase involved the extermination of bad data points with too large or too small resistivity values corresponding to high or low spikes, respectively. Bad data points were due to the failure of the relays at one of the electrodes, poor electrode contact arising from dry soil, and/or shorting across the cables.

Least square inversion modelling was employed to determine the subsurface apparent resistivity distribution through adjusted change and inversion setting parameters. The adjusted parameters included model refinement using cell widths of half electrode spacing for optimum results and finite element method of 4 nodes to achieve accurate calculated apparent resistivity values, particularly for large resistivity contrasts. $\mathrm{L}_{1}$ norm (robust inversion) was employed for more stable results $[15,16]$. The vertical/horizontal flatness ratio filter of 0.5 was used for better resolution of anomaly appearances. Damping factor of 0.1 with minimum of 0.02 (one-fifth of the initial value) was used to stabilise the inversion process and to increase the certainty that the identified anomalies actually exist $[17,18]$. Inverse model convergence 
RMS limit below $10 \%$ was chosen for a maximum of 10 iterations. Finally, standard GaussNewton method was used for the calculation of sensitivity matrix.

\section{Results and Discussion}

The detailed interpretation of inverse model resistivity section from electrical imaging demands considerable practical experience of the method on the one hand, and on the other hand, a sound knowledge of the geology of the area under consideration. The interpretation of the inverse model resistivity sections is done using the geological information (rocks and structural features) of the study area and environs provided in the works of Refs. [6-8] and other information from failed hand-dug wells; such information includes but not limited to the nature of subsurface constituents and depth to bedrock. The above mentioned information with the range of resistivity values encountered in the inverse model resistivity sections, a detailed subsurface interpretation of the inverse model resistivity sections, is obtained.

The 2D resistivity inversion considerably provides robust image of the subsurface geology. It places the structures at approximately their correct depths and provides acceptable estimates of their true resistivities. The 2D inverse model resistivity sections of high resolution and quality target definition for the area investigated are shown in Figures 3 and 4.

A 2D inverse model resistivity section of TR 1 along Iyanu Jesu Street in Etioro-Akoko is shown in Figure 3. The subsurface is characterised by four distinct subsurface layers of varying resistivity responses. The first layer (topsoil) is characterised by surficial soil typical of clay medium with resistivity generally below $100 \Omega \mathrm{m}$ and thickness of about $0.4-2.0 \mathrm{~m}$. The second layer is characterised by weathered materials typical of clayey sand/sandy clay/sand with resistivity ranging from 50 to $450 \Omega \mathrm{m}$ and depth of about $12 \mathrm{~m}$. The partially weathered bedrock intersperse the topsoil at stations $17-20 \mathrm{~m}$, $120-125 \mathrm{~m}$ and $170 \mathrm{~m}$ and beyond. Stations $10-60 \mathrm{~m}, 100-120 \mathrm{~m}$ and $150-160 \mathrm{~m}$ along the traverse are delineated as possible weak zones marked by resistivity patterns ranging from
480 to $800 \Omega \mathrm{m}$. These sections are indicative of the partially weathered/fractured bedrock (third layer). The fresh bedrock which is the basal unit has resistivity that is generally greater than $1000 \Omega \mathrm{m}$. The fresh bedrock is marked by gently undulating to broad crested surface. It extends to the surface between stations 160 and $170 \mathrm{~m}$. The topsoil and weathered bedrock form the overburden with thickness ranging from $<4$ to $15 \mathrm{~m}$. Sections with high overburden thicknesses are characterised by localised bedrock depressions occasioned by fracturing (F-F') and deep weathering of less stable rock minerals such as feldspar and amphiboles. The zones are suggestive of the accumulation and conduits for groundwater. Stations $40 \mathrm{~m}$ and $110 \mathrm{~m}$ of TR 1 display these characteristics. The aquifer characteristics and geometries of these two groundwater zones have potential for high groundwater yield due to aquifer characteristics such as low clayey content, trough-like structures and appreciable overburden thicknesses as conduits and groundwater storage/ collecting centres. However, other stations on the traverse are zones with shallow overburden thicknesses. The groundwater productivity level of the Kamomi community borehole, which is the most productive borehole in the area, corroborates the success rate of the result for station $40 \mathrm{~m}$.

Figure 4 shows the inverse model resistivity section of TR 2 along a rugged street from surface observation. TR 2 shows four distinct subsurface layers of varying resistivity responses. The first layer (topsoil) is characterised by surficial soil typical of clayey medium, with resistivity generally below $150 \Omega \mathrm{m}$ and thickness of about $0.3-1.5 \mathrm{~m}$. The topsoil is interspersed by high resistivity responses particularly at stations $20-60 \mathrm{~m}, 120-135 \mathrm{~m}$ and $145 \mathrm{~m}$. The second layer is characterised by weathered materials typical of clayey sand/sandy clay/sand with resistivity ranging from 160 to $650 \Omega \mathrm{m}$. The weathered materials show evidence of low resistivity response that extends to the depth of about $25 \mathrm{~m}$ and $11 \mathrm{~m}$ at stations $85-128 \mathrm{~m}$ and $157 \mathrm{~m}$ westward respectively. This low resistivity response is suggestive of saturated weathered bodies. Partially weathered/ fractured bedrock (third layer) is delineated at stations $130-160 \mathrm{~m}$ with resistivity values 


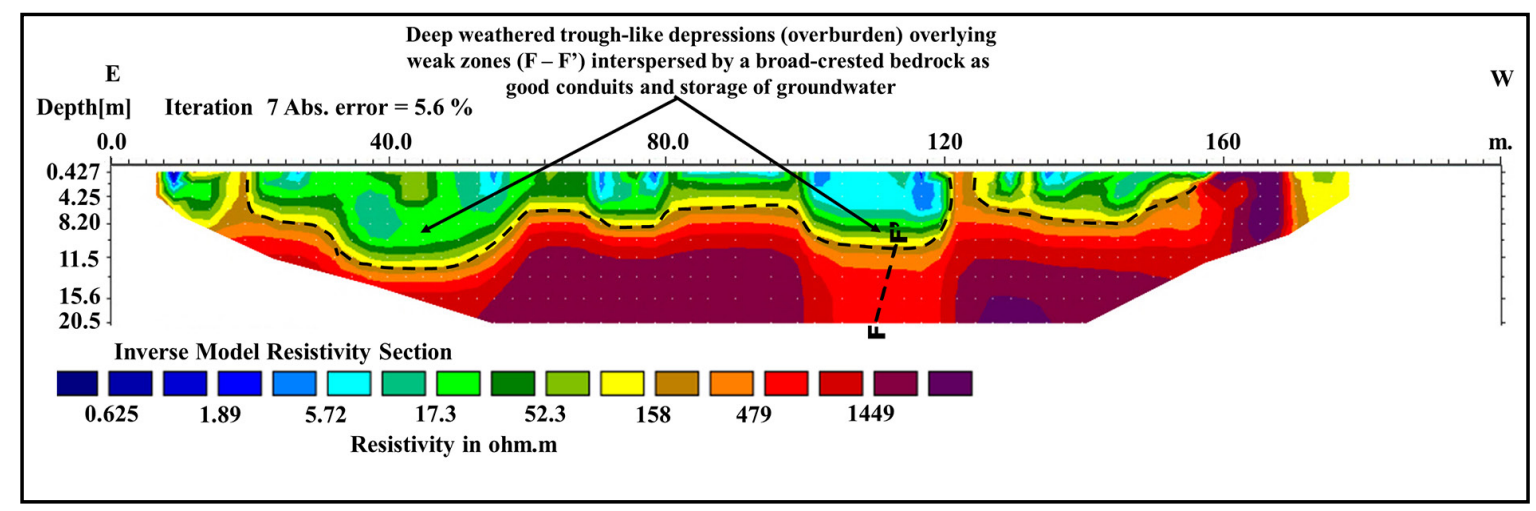

Figure 3: The inverse model resistivity section of traverse (TR) 1.

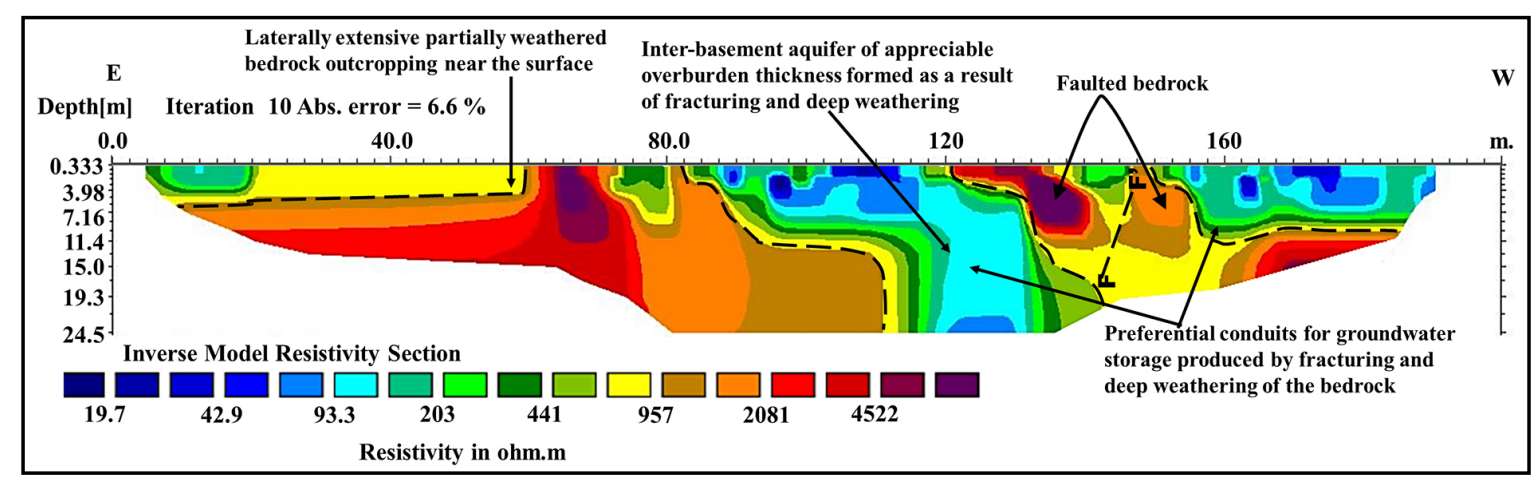

Figure 4: The inverse model resistivity section of traverse (TR) 2.

of $660-900 \Omega \mathrm{m}$. The basal unit which is the fresh bedrock is characterised by resistivity generally above $1000 \Omega \mathrm{m}$. The fresh bedrock is discontinued at some sections by fractures and deep weathered troughs to produce localised depressions which may have resulted from active fluids/seepages and other geological activities. The localised depressions extend beyond the depth of $24.5 \mathrm{~m}$ and $12 \mathrm{~m}$ at stations $110-128 \mathrm{~m}$ and $160 \mathrm{~m}$ westward respectively. These delineated features enhance the groundwater potential of the area in spite of its ruggedness.

Station $120 \mathrm{~m}$ of TR 2 is considered as probable zone for the siting of borehole because the zone is suggestive of high groundwater yield owing to good degree of water saturation and overburden thickness greater than $25 \mathrm{~m}$. From station $160 \mathrm{~m}$ westward, points are considered to have moderate groundwater yield. The mechanised hand-pump borehole is situated about $20 \mathrm{~m}$ northward from these stations.
As shown in Figures 3 and 4, two hydrogeological/aquifer zones were identified. The hydrogeological zones include the following: overburden-dependent aquifers on the fairly and highly deep weathered bedrock, and fractured dependent aquifers on the fractured bedrock column. The hydrogeological zones are significant for high yielding groundwater boreholes and wells in the area. Possible hydrogeological zones aside the locations of the existing wells/boreholes include zones between stations $90 \mathrm{~m}$ and $120 \mathrm{~m}$ of TR 1 and stations $110 \mathrm{~m}, 120 \mathrm{~m}$ and $160 \mathrm{~m}$ of TR 2 . These zones are characterised by zones of weaknesses (fractured/faulted bedrocks) with localised deep and elongated weathered bedrock troughs (bedrock depressions) of appreciable overburden thicknesses not less than $12 \mathrm{~m}$. The deep and elongated weathered/fractured bedrock depressions are envisaged for high groundwater storage and discharge tendencies in few places in the study area. 


\section{Conclusion}

In this study, multi-electrode electrical resistivity tomography was employed for delineating the subsurface hydrogeological features for sustainable groundwater development to ameliorate the challenges posed on groundwater supplies in Etioro-Akoko, southwestern Nigeria. The results of the inverse model resistivity sections along two traverses generally show four subsurface layers. These include the topsoil, fairly to highly weathered layer, partially weathered/fractured bedrock and fresh bedrock. The overburden section is composed of constituents of the topsoil and weathered/partially weathered bedrock. The overburden-dependent and fractured dependent aquifers were delineated as the hydrogeological zones/aquifer regimes in the area. The depth to bedrock varied from less than $4 \mathrm{~m}$ to greater than $12 \mathrm{~m}$. Deep and elongated weathered columns are indicative of localised bedrock depressions in few places. The depressions are occasioned by weathering of less stable minerals such as amphibole, feldspar and mica within the bedrock. These features enhance the channelling and accumulation of groundwater. It is envisaged that the proposed hydrogeological zones are significant for the siting of wells and boreholes in addition to the existing servicing wells and boreholes for sustainable groundwater supply in EtioroAkoko community.

However, indiscriminate siting of dumpsite practices be disabused in the study area as the thin overburden covers $(<4 \mathrm{~m})$ in most places may not act as effective barriers/filters against surface contaminants or leachates that degrade groundwater quality. Biochemical and microbial analyses of groundwater may be carried out to ascertain the quality of groundwater for consumption by inhabitants in the study area.

\section{Acknowledgements}

The authors are grateful to Messers Abimbola C. Ogunyele, Olaniyi R. Ijaleye and Moses Salami for their field assistance. Anonymous reviewers are acknowledged for comments that have made the manuscript more readable.

\section{References}

[1] Griffiths, D.H., Barker, R.D. (1993): Two-dimensional resistivity imaging and modeling in areas of complex geology. Journal of Applied Geophysics, 29, pp. 211-226.

[2] Barker, R., Moore, J. (1998): The application of timelapse electrical tomography in groundwater studies. Leading Edge, 17, pp. 1454-1458.

[3] Osazuwa, I.B., Chii, E.C. (2010): Two-dimensional electrical resistivity survey around the periphery of an artificial lake in Precambrian Basement Complex of Northern Nigeria. International Journal of Physical Sciences, 5(3), pp. 238-245.

[4] Costall, A., Harris, B., Pigois, J.P. (2018): Electrical Resistivity Imaging and the Saline Water Interface in High-Quality Coastal Aquifers. Survey Geophysics, pp. 1-64. https://doi.org/10.1007/s10712-018-9468-0.

[5] Akingboye, A.S., Ogunyele, A.C. (2019): Insight into seismic refraction and electrical resistivity tomography techniques in subsurface investigations. The Mining-Geology-Petroleum Engineering Bulletin, 34(1), pp. 93-111. doi: 10.17794/rgn.2019.1.9.

[6] Aminu, M.B. (2015): Electrical Resistivity Imaging of a Thin Clayey Aquitard Developed on Basement Rocks in Parts of Adekunle Ajasin University Campus, Akungba-Akoko, South-western Nigeria. Environmental Research, Engineering and Management, 71(1), pp. 47-55. http://dx.doi.org/10.5755/ j01.erem.71.1.9016.

[7] Mohammed, M.Z., Ogunribido, T.H.T., Adedamola, T.F. (2012): Electrical Resistivity Sounding for Subsurface Delineation and Evaluation of Groundwater Potential of Araromi Akungba-Akoko. Ondo State, Southwestern Nigeria. Journal of Environment and Earth Science, 2(7), pp. 29-40.

[8] Okpoli, C., Saba, E.A. Oduneye, O.C. (2014): Geophysical Investigation of Groundwater Regime: Case Study of Etioro-Akoko, Southwestern Nigeria. Environmental Research, Engineering and Management, 69(3), pp. 29-39. http://dx.doi.org/10.5755/ j01.erem.69.3.5334.

[9] Abu-Hassanein, Z., Benson, C., Blotz, L. (1996). Electrical resistivity of compacted clays. Journal of $\mathrm{Ge}$ otechnical Engineering, 122, pp. 397-406. https:// doi.org/10.1061/(ASCE)0733-9410.

[10] Hassan, A.A. (2014): Electrical Resistivity Method for Water Content Characterisation of Unsaturated Clay Soil. Durham Theses, Durham University. Available from: Durham e-theses online. http://etheses.dur.ac.uk/10806/. 
[11] Merritt, A.J. (2014): 4D Geophysical Monitoring of Hydrogeology Precursors to Landslide Activation. PhD Thesis, School of Earth and Environmental, University of Leeds, UK. 1-276.

[12] Ojo, S.O. (2000): Factor productivity in maize production in Ondo state Nigeria. Applied Tropical Agriculture, 23, pp. 25-26.

[13] Rahaman, M.A. (1989): Review of the Basement Geology of South-Western Nigeria. In: Kogbe, C.A. (eds.). Geology of Nigeria (2nd eds.). Rockview Nige Limited, Jos., pp. 39-56.

[14] Obaje N.G. (2009): Geology and Mineral Resources of Nigeria. Heidelberg, Berlin: Springer-Verlag. 221 p. doi: 10.1007/978-3-540-92685-6.
[15] Zhou, B., Dahlin, T. (2003): Properties and effects of measurement errors on 2D resistivity imagine survey. Near surface geophysics, 1(3), 105-117.

[16] Dahlin, T., Zhou, B. (2004): A numerical comparison of 2D resistivity imaging using 10 electrode arrays. Geophysical Prospecting, 52, 379-398.

[17] deGroot-Hedlin, C., Constable, S.C. (1990): Occam's inversion to generate smooth two-dimensional models from magnetotelluric data. Geophysics, 55, 1613-1624.

[18] Loke, M.H. (2004): Rapid 2D resistivity and IP inversion using the least-square method. Manual for RES2DINV, version 3.54.53 p. 